\title{
BRETON, TROTSKY Y RIVERA: MÉXICO Y LA ESPERANZA SURREALISTA \\ Armando Pereira*
}

RESUMEN: En este ensayo, se trata de explorar las razones que determinaron la decisión de André Breton de abandonar Francia, en 1938, y refugiarse en México. Se analiza también la imagen, más cercana al surrealismo que a nuestra realidad, que el poeta francés nos deja de nuestro país. Y, sobre todo, su estrecha relación con Trotsky y Rivera, que lo llevó a escribir, junto con ellos, el manifiesto Por un arte revolucionario independiente, en el que se considera esencial el respeto a la libertad irrestricta del artista en la concepción de su obra, al margen de cualquier condicionamiento ideológico.

$$
\text { sose }
$$

ABSTRACT: In this article, we explore the reasons that led André Breton to flee France in 1938 and seek refuge in Mexico. Moreover, we will analyze his image of Mexico, closer to surrealism than our common experience. In addition, we will examine his close relationship with Trotksky and Rivera, which led to their collaboration on the manifesto for an Independent and Revolutionary Act, in which an artist's unlimited freedom in his work is of outmost importance notwithstanding any ideological conditioning.

PALABRAS CLAVE: Breton, Trostsky, Rivera, México, surrealismo.

KEY WORDS: Breton, Trotsky, Rivera, Mexico, surrealism.

RECEPCIÓN: 01 de mayo de 2011.

APROBACIÓN: 24 de mayo de 2011.

* Centro de Estudios Literarios, Instituto de Investigaciones Filológicas, UNAM. 
CITAM Derechos Reservados.

La reproducción total o parcial de este artículo se podrá hacer si el ITAM otorga la autorización previamente por escrito. 


\title{
BRETON, TROTSKYY RIVERA: MÉXICO Y LA ESPERANZA SURREALISTA
}

\begin{abstract}
Al recordar su estancia en México, Breton rescata tres imágenes fundamentales en las que parece que ha quedado cifrado su recuerdo. El texto está escrito en 1938, cuando todavía esos ideales eran vigentes:
\end{abstract}

1. Ese hombre vestido de andrajos junto a un cactus gigante, con el sombrero ancho hasta la mitad de la frente y sosteniendo un fusil. Para Breton, se trata de una imagen emblemática del México revolucionario, de ese "país donde el viento de la liberación no ha amainado". ${ }^{1}$ Destaca dos fechas: 1810 (la guerra de Independencia contra la Corona española) y 1910 (la Revolución mexicana). Aunque el tiempo ha pasado, ese campesino revolucionario sigue allí, vigilante, decidido a perpetuar los ideales por los que lucharon sus padres y sus abuelos. "Siglos de opresión y de loca miseria le han conferido, en dos ocasiones, una deslumbrante realidad, y nada puede impedir que esa realidad no permanezca latente, que no siga incubándola la aparente somnolencia de las extensiones desérticas. El hombre armado está siempre allí, con sus espléndidos andrajos, como sólo él puede elevarse súbitamente desde la inconsciencia y la desgracia".2

${ }^{1}$ André Breton, La llave de los campos, 1976, Madrid, Libros Hiperión, I. Peralta Ediciones y Ediciones Ayuso, p. 33.

${ }^{2}$ Ibid. 
ARMANDO PEREIRA

2. La segunda imagen es la del México precolombino: las ruinas de las pirámides indígenas devoradas por la maleza y los arbustos, pero que aun, a pesar de su estado deplorable, a pesar de su hiriente abandono, "cargan el aire de electricidad". ${ }^{3} \mathrm{O}$ bien, la imagen de ese indígena junto a uno de los templos de Bonampak, en Chiapas, recién rescatado de la selva, después de guiar hasta allí a un investigador francés, Gilles G. Healey, a quien se debe el descubrimiento de los frescos que decoran el templo. Lo que lamenta Breton es que ese camino abierto al investigador pronto se convertirá en una amplia avenida que llevará hasta allí a las hordas de turistas "congénitamente hastiados": "tarde o temprano los frescos de Bonampak habrán de sufrir el paciente e interminable desfile de los imbéciles" o el saqueo mercenario de los comerciantes que convertirán la cerámica sagrada de Bonampak "en pura y simple mercancía internacional". ${ }^{4}$ Una actividad, por cierto, a la que, unos años después, se dedicará para sobrevivir en México uno de sus viejos amigos y fiel correligionario de surrealismo: Benjamin Péret. En fin, Breton concluye este segundo recuerdo con una afirmación que tiene la fuerza de un pronóstico: "México, mal despierto aún de su pasado mitológico, continúa evolucionando bajo la protección de Xochipilli, dios de las flores y de la poesía lírica, y de Cuatlicue, diosa de la tierra y de la muerte violenta. [...] Este poder de conciliación de la vida y la muerte es, sin duda alguna, el principal atractivo de que dispone México". 5

84 3. La última imagen que llama la atención de Breton es un palacete colonial, de arquitectura y decoración barrocas, también en ruinas, en el que habitan, como silenciosas sombras o fantasmas de otros tiempos, los últimos sobrevivientes de la raza invasora y ahora vencida. Uno de ellos, precisamente el que ha heredado el palacio, ha perdido la razón y, mientras guía a Breton por habitaciones y pasillos, divaga enfebrecido recordando las glorias efimeras de una familia devorada por el tiempo y ahora usurpada en sus bienes por sus propios criados, como una forma de cobrarse, ellos, lo que esa familia ha quedado debiéndoles a lo largo de los años de decadencia.

Sólo tres imágenes en el recuerdo, pero tres imágenes que recuperan a México en momentos cruciales de su historia, desde el pasado

\footnotetext{
${ }^{3}$ Ibid., p. 34.

${ }^{4}$ Ibid., p. 152.

${ }^{5}$ Ibid., pp. 34-5.
} 
precolombino hasta el presente revolucionario. Aunque, hay que decirlo, son tres imágenes que le deben más al folklore europeizante que a la realidad profunda de México.

Y es que, de hecho, México no representaba ningún interés particular para André Breton, como tampoco lo sería, años después, para Benjamin Péret. En 1952, en una entrevista con André Parinaud, Breton declararía que con el viaje a México "se realizaba una de las más grandes aspiraciones de mi vida. Por escasa que sea mi vocación por los viajes, México, debido tal vez a los recuerdos de mi infancia, era entre todos los países el que más me atraía". ${ }^{6}$ Parece que este anhelo infantil de México no es más que una reconstrucción nostálgica a posteriori. Breton no vino a México a buscar nada; sobre todo, no vino dispuesto a encontrar a México. No había nada en México que decidiera su viaje. O bien, lo que había aquí, y que era lo que en realidad le interesaba al líder de la revolución surrealista, no tenía mucho que ver con México. Creo que hay que distinguir entre las declaraciones y los hechos: la estancia de cuatro meses de Breton en el territorio mexicano demuestra que México no le importaba mucho a Breton, que lo que realmente le importó de México fue Trotsky. Jean Marie Le Clézio confirma lo que, para mí, al principio de este ensayo, era sólo una intuición: si Breton elige venir a México, en lugar de a Checoslovaquia, es porque sabe de antemano que aquí podrá encontarse con León Trotsky e intercambiar ideas sobre el arte y la revolución proletaria. “André Breton ha venido a México para encontrarse con Trotsky -él ha sido igualmente excluido del Partido Comunista dos años después que Rivera- y redactar con él el manifiesto de la Federación Internacional de Artistas Revolucionarios Independientes - manifiesto que lleva la marca evidente de las ideas trotskistas que afirman la necesidad de la emancipación total del intelectual". ${ }^{7}$

No creo siquiera que en realidad quisiera venir a México, que el viaje a México formara parte de su deseo. Sus preocupaciones en ese

${ }^{6}$ André Breton, Entretienes avec André Breton, 1969, Paris, Gallimard. Cf. también Fabienne Bradu, André Breton en México, 1996, México, Ed. Vuelta, p. 31.

${ }^{7}$ Jean Marie Gustave Le Clézio, Diego et Frida, 1993, Paris, Gallimard, pp. 215-6. La traducción de todas las citas de Le Clézio en este ensayo es mía. 
ARMANDO PEREIRA

momento no rebasaban los márgenes europeos, se centraban en la agitada vida política y cultural de la capital francesa. Si decidió hacer un viaje al extranjero, fue tan sólo obligado por circunstancias económicas: "Por no haber consentido ni en la primera ni en la segunda de tales capitulaciones [someter su pensamiento a las exigencias ideológicas de la sociedad burguesa o del estalinismo francés], la extrema precariedad de mi situación material - puntualiza Breton-me obligó hace dos años a solicitar un puesto de enseñanza en el extranjero". ${ }^{8}$ El Ministerio de Asuntos Exteriores de Francia le ofreció dos países que, a su juicio, estaban libres de la voluntad totalitaria que por entonces (1938) recorría a casi toda Europa: Checoslovaquia y México. Checoslovaquia, hundida en sus frías alturas burocráticas (de las que Kafka había dado ya sobrada cuenta), no le ofrecía gran cosa a la furia surrealista y revolucionaria del poeta francés, no era un país que vibrara al ritmo de esas dos pasiones bretonianas: la revolución surrealista no había dejado la menor huella allí. México, en cambio, era un país joven, todavía en plena efervescencia revolucionaria. Breton, sin pensarlo mucho, optó por México, quizá repentinamente entusiasmado por su proverbial exotismo, pero también por el hecho de que México había sido el único refugio que Trotsky había encontrado para escapar al terror y a la persecución estalinista y la certeza de un enriquecedor intercambio ideológico con el líder sobreviviente de la Revolución de Octubre. Estuvo en México escasos cuatro meses, de abril a agosto de 1938. Y su compromiso consistía en dictar, en la Universidad Nacional Autónoma de México, una serie de conferencias sobre la situación de la poesía y la pintura en Europa.

Todavía antes de abandonar París, las campañas políticas en su contra proliferaban. Tristan Tzara, durante el dadaísmo y los primeros años del surrealismo, había sido su amigo. Breton lo había recibido calurosamente en París y habían caminado de la mano un cierto trecho por los callejones y avenidas de la agitada vida intelectual francesa de la época. Pero, de pronto, esas manos se crisparon, devinieron puños que estuvieron a punto de resolver su estrecha amistad a golpes. Ahora, en vísperas de su viaje a México, es Tzara el que inicia las decargas verba-

${ }^{8}$ André Breton, La llave de los campos, op. cit., p. 50. 
les contra Breton: "Antes incluso de mi marcha, un miembro de la 'Casa de la Cultura', un majadero bastante peligroso llamado Tristan Tzara, encontraba oídos a los que confiar ique yo iba encargado por Asuntos Exteriores de una misión cerca de Trotsky". 9

En realidad, la vida de Breton está recorrida por polémicas constantes y rupturas violentas con los que habían sido sus compañeros de ruta en el movimiento surrealista. En 1935, junto con Benjamin Péret, se separa del Partido Comunista Francés, por considerarlo un partido carente de voz propia y sometido a las directrices estalinistas de Moscú. Por esos años, rompe también con dos amigos que, hasta entonces, habían sido entrañables para él: Louis Aragon y Paul Eluard que, a difrencia de él y de Péret, deciden mantenerse fieles a su militancia comunista. No es casual, entonces, que de 1935 a marzo de 1938, fecha en la que se embarca rumbo a México, esos ataques, destinados a desvirtuar su imagen política, hayan sido una constante en París.

Pero no fue sólo en Francia donde se calumnió a Breton y a la misión intelectual que debía desempeñar del otro lado del Atlántico. Esas descalificaciones rebasaron pronto las fronteras europeas y llegaron incluso al país que iba a recibirlo. "Al mismo tiempo que yo, salían de París, vía Nueva York, a México por avión -de modo que me precedieron- cierto número de cartas dirigidas a los principales artistas y escritores mexicanos, cartas en las que se daba libre curso a las calumnias más desvergonzadas". ${ }^{10}$ Uno de esos intelectuales mexicanos, que desde un principio descreyó de la farsa montada en torno a Breton, le hizo llegar la carta que había recibido. Breton, seguramente para no perjudicarlo, guarda el anonimato de ese amigo mexicano, pero lo que sí hace es reproducir la carta completa:

Querido camarada y amigo:

Deseamos informarle, rogándole tenga la bondad de ponerlo en conocimiento de nuestros amigos de México, sobre la postura del señor André Breton, que debe llegar a su país para pronunciar en él algunas conferencias.

${ }^{9}$ Ibid., p. 51.

${ }^{10}$ Ibidem. 
Enviado por los servicios de propaganda del Ministerio de Asuntos Exteriores, cuya política reaccionaria es aún hoy bien conocida, el señor André Breton ha adoptado siempre una postura contraria al Frente Popular, aliándose con este fin con los elementos políticos más dudosos. Su acción contra la República española ha adoptado las formas más pérfidas, si bien siempre apelase a un vago revolucionarismo verbal.

Admirador declarado de Trotsky, siempre ha impugnado todas las acciones de la Asociación Internacional de Escritores, vetándosele la palabra por tal razón durante el primer Congreso de Escritores.

Ante el temor de que pudieran producirse malentendidos, hemos querido tenerle al corriente de la verdadera situación de la literatura en Francia.

Crea..., etc.

Por el Secretariado Internacional:

Firmado: René Blech. ${ }^{11}$

Esas calumnias y descalificaciones estalinistas eran el pan de los días y las noches de la política de los partidos comunistas, tanto en Europa como en América, todos ovejas obedientes del Gran Pastor de Moscú. Breton nunca estuvo contra el Frente Popular, aunque sí sometió a crítica sus posturas serviles y sumisas. Él y todos los surrealistas se pronunciaron siempre insistentemente en favor si no de la República española, a la que consideraban una República burguesa, sí, en cambio, desde una perspectiva hasta cierto punto anarquista, de una España obrera y revolucionaria, y en contra del levantamiento armado que, a la larga, llevaría a Franco al poder. Fueron siempre claras y firmes sus declaraciones en contra de la política intervencionista de italianos y alemanes que terminarían inclinando la balanza en favor de las fuerzas más regresivas de España. Y aunque no era necesario, por lo tanto, volver a enfatizarlo, el poeta francés decide hacerlo una vez más, quizá para que no quepa la menor duda, en su discurso pronunciado en el mitin de aniversario de la Revolución de Octubre organizado por el P.O.I. en París, el 11 de noviembre de 1938, a su regreso de México:

Para aquellos de vosotros que lo ignorasen, yo quiero recordar, camaradas, que mi actitud y la de mis amigos surrealistas con respecto ${ }^{11}$ Ibidem. 
a la guerra de España jamás se ha prestado al menor equívoco. Desde el comienzo del conflicto, nosotros repudiamos para siempre las fuerzas de regresión y de tinieblas que asumían la responsabilidad de ponerlo en marcha; hemos proclamado nuestra inquebrantable esperanza en ese empuje inicial que proyectó hacia adelante a la España obrera y que tendía a la realización, templada en el peligro, de su unión, única verdaderamente invencible; que tendía también al primordial aniquilamiento de todo el aparato religioso y, por encima de todo, a la constitución de una ideología revolucionaria activa, formada en la prueba de los hechos. ${ }^{12}$

Lo que en realidad molestaba de Breton fue la postura crítica que mantuvo en todo momento ante la Unión Soviética y Stalin, el haber criticado los procesos de Moscú y las prácticas totalitarias y represivas que se desarrollaban allí y, en lo que respecta a España, por haber considerado que "la U.R.S.S. actual constituye uno de los principales obstáculos para la victoria del proletariado español [...] para Stalin de lo que se trata es de impedir a cualquier precio que una nueva oleada revolucionaria se vuelque sobre el mundo. Se trata de abortar la revolución española en la misma forma que se abortó la revolución alemana, la china". ${ }^{13}$ Habría que recordar que en los años de la República y más tarde durante la guerra, en España se movieron fuerzas políticas muy diversas y complejas. Entre ellas, por ejemplo, estaban los anarquistas, con Durruti y Ascaso a la cabeza - una corriente a la que el poeta francés fue ideológicamente muy afecto--, que postulaban, más que la restauración de la República, el triunfo de la revolución proletaria por medio de ella.

En ese sentido apunta el alegato de Breton contra la participación de la Unión Soviética en la guerra de España: “¿Se nos objeta que la U.R.S.S. suministra armas, aviones? Sí, pero porque esas armas de doble filo están abocadas a quebrantar todo cuanto en España trabaja no ya en favor de la restauración de la república burguesa, sino por el establecimiento de un mundo mejor; porque están destinadas a destruir todo lo que lucha por la revolución proletaria". ${ }^{14} \mathrm{Y}$ un poco más adelante

${ }^{12}$ Ibid., p. 52.

${ }^{13}$ Ibidem.

${ }^{14}$ Ibidem. 
ARMANDO PEREIRA

puntualiza: "No nos engañemos, las balas de la escalera de Moscú, en enero de 1937, están dirigidas contra nuestros camaradas del P.O.U.M. Después de ellos serán nuestros camaradas anarquistas los que se tomarán como blanco, con la esperanza de terminar así con todo lo que hay de vivo, con todo lo que lleva consigo una promesa de transformación en la lucha antifascista española". ${ }^{15}$

En fin, son estas críticas a la política estalinista, tanto en el interior de la U.R.S.S. como en la guerra de España, las que le valieron a Breton esas cartas, cargadas de insultos y vejaciones, que lo precedieron a su llegada a México y que debían advertir a intelectuales y artistas mexicanos del peligro que significaba la difusión de las ideas del surrealista francés.

En otra de esas cartas, dirigida al secretario general de la Liga de Escritores y Artistas Revolucionarios, se pedía, sin ambages, "sabotear sistemáticamente todo el trabajo al que yo quisiera dedicarme en México". ${ }^{16}$ El que firmaba la carta era el poeta Louis Aragon, no sólo amigo de Breton durante los primeros años del surrealismo, sino firme y cercano compañero de viaje en esa empresa poética durante más de diez años. Ahora, desde la tribuna del Partido Comunista Francés, Aragon pedía, de la manera más aviesa, que se saboteara la actividad en México de quien en otro tiempo había sido uno de sus amigos más entrañables.

Hay un solo punto en el que la carta de René Blech, citada anteriormente, tenía razón: la franca admiración que Breton sentía por León Trotsky, no porque viniera a desempeñar una oscura misión cerca de él, sino por lo que Trotsky significaba para el mundo entero en esos años: compañero de Lenin, creador del Ejército Rojo y el último de los dirigentes sobrevivientes de la Revolución de Octubre. Stalin, unos años antes, había mandado fusilar a todos los integrantes de la vieja guardia leninista, por considerarlos un posible obstáculo a su poder omnímodo y a la implantación de su política autoritaria y represiva en toda la Unión Soviética. Trotsky no tuvo otra alternativa que optar por el largo camino del exilio que terminaría conduciéndolo a México, un país al

${ }^{15}$ Ibid., pp. 52-3.

${ }^{16}$ Ibid., p. 53. 
que supuso erróneamente que no sería alcanzado por los tentáculos asesinos del dictador moscovita.

Después de su expulsión de Noruega, y de que el presidente Roosvelt les hubiera negado la estancia en el territorio de Estados Unidos, León Trotsky y Natalia Sedova desembarcan en el puerto de Tampico, adonde Frida Kahlo ha ido a recibirlos en nombre de Diego. Y será en casa de Frida, en Coyoacán, donde el matrimonio ruso encontrará, al fin, refugio:

Gracias a la intervención de Rivera ante Lázaro Cárdenas, el nuevo presidente de México -escribe Le Clézio-, el proscrito puede al fin encontrar asilo. Para Diego Rivera, Trotsky representa el ideal revolucionario, el hombre que se sacrifica totalmente por sus ideas, el hombre que encarna verdaderamente la Internacional Comunista. Conmovido por la suerte del fundador del Ejército Rojo, Lázaro Cárdenas, en un gesto fraternal, envía a Tampico su tren personal, El Hidalgo, y Trotsky se instala con su equipo de colaboradores (secretarios, guardaespaldas) en la casa de Frida en Coyoacán, que deviene enseguida el nuevo centro de la Internacional Trotskista -allí, desde ahora, el jefe revolucionario redacta sus comunicados, sus tomas de posición, organiza su defensa contra el poder de Stalin. ${ }^{17}$

Y precisamente allí, a la casa-refugio-búnker de Trotsky, se dirige Breton a los pocos días de llegar a la capital mexicana, lleno de entusiasmo: "Heme aquí encaminándome, ya adivinaréis con qué emoción, hacia la 'casa azul' de la que tanto se ha hablado y que es la residencia en Coyoacán del camarada Trotsky". ${ }^{18}$ Nada más traspasar el viejo portón de madera, Breton es conducido hasta el gabinete del dirigente ruso. Y, a su paso, no deja de admirar la belleza de la casa que Diego Rivera y Frida Kahlo han puesto a disposición del exiliado: los jardines llenos de bugambilias, violetas y cactus gigantes, las veredas estrechas que conducen al gabinete bordeadas de esculturas de Diego, la casa espaciosa llena de luz y de libros. De pronto, desde

${ }^{17}$ Jean Marie Gustave Le Clézio, op. cit., p. 213.

${ }^{18}$ André Breton, La llave de los campos, op. cit., p. 53. 
el fondo de una de las habitaciones, un hombre fuerte y lleno de vida se pone de pie y abraza a Breton: "Los ojos de un azul profundo, la admirable frente, la abundancia de los cabellos apenas plateados, la lozanía de la tez, componen una máscara donde se siente que la paz interior ha vencido, que vencerá siempre a las formas más crueles de la adversidad". ${ }^{19}$

León Trotsky había llegado a México en enero de 1937, como señalé antes, gracias a la intercesión de Diego Rivera ante el presidente Lázaro Cárdenas, quien no sólo no puso ninguna objeción para recibirlo, sino que además dispuso fuerzas de seguridad para protegerlo y desalentar cualquier posible acción en su contra. Ese será siempre uno de los valores indiscutibles del pueblo y de los gobiernos mexicanos: el haber construido un país abierto, acogedor y solidario con cualquiera que por razones políticas acuda a él en busca de asilo o refugio. Si ahora recibía a un revolucionario ruso perseguido por el terror de Stalin a quien varios países le cerraron sus puertas, dos años más tarde acogería calurosamente también a miles de españoles que huían de los paredones de fusilamiento o de las cárceles franquistas. Allí, en su 'casa azul' de Coyoacán, Trotsky podía seguir pensando y escribiendo. Y es esta fraterna y desinteresada actitud del gobierno mexicano la que destaca Breton en algún momento de su discurso:

Es de justicia rendir al gobierno de Cárdenas homenaje por cuanto continúa por todos los medios asegurando la seguridad del camarada Trotsky. Los miembros de aquel gobierno, algunos de los cuales han desempeñado grandes papeles en la revolución de 1910, han combatido bajo las órdenes de Zapata o han sido formados en su escuela, admiran sin reservas a un hombre del temple de Trotsky. No es culpa de ellos, sino consecuencia de las medidas de protección que han de tomar con él, si padece al no poder desplazarse como quisiera. ${ }^{20}$

Y, en realidad, la hermosa casa de Coyoacán, donde Trotsky vivía junto a su fiel y amada Natalia, constituía, para ellos, una suerte de cómo-

${ }^{19}$ Ibid., p. 54.

${ }^{20}$ Ibid., p. 58. 
do y agradable reclusorio. En alguna ocasión, y refiriéndose a su nueva vida mexicana, el propio Trotsky hizo el siguiente comentario ante su secretario, Joseph Hansen: "Esto no es un hogar: es una prisión medieval". ${ }^{21}$

No quiero decir con esto, sin embargo, que el revolucionario ruso viviera encerrado a piedra y lodo en su 'casa azul' a las afueras de la ciudad de México. André Breton ha relatado someramente algunos de los viajes que hizo con Trotsky y Diego Rivera por distintas regiones del país: Cuernavaca, el Popocatépetl, Puebla, Cholula, Pátzcuaro, Michoacán, Guadalajara. O esa tarde en la que se internaron los dos hasta:

el corazón de uno de esos mercados indios, que son uno de los espectáculos más bellos que ofrece México. Ya nos interesáramos por la arquitectura de las edificaciones de la plaza, o por los puestos multicolores, o por el paso de los aldeanos cubiertos con sus sarapes que conjugan el sol y la noche, o por la extraordinaria nobleza de su caminar, Trotsky encontraba siempre el medio de enlazar el menudo hecho observado con un dato más general, de imprimirle un giro integrador en la esperanza de un reajuste de los valores de este mundo, de extraer de él un estímulo en favor de nuestra lucha. ${ }^{22}$

Esos viajes y las largas conversaciones que sostenían los dos amigos lograron estrechar la relación entre ellos y le permitieron a Breton humanizar, en su interior, la figura un tanto idealizada del dirigente revolucionario: "De la vida un tanto legendaria que yo le prestaba pasó para mí a la existencia más real, más tangible". ${ }^{23}$ El retrato que Breton hace de Trotsky nos muestra a un hombre inquieto, inteligente, bromista, interesado en todo lo que le rodea, y resume esa imagen en una palabra: seducción.

Esta seducción es extrema. Una tarde en la que había aceptado recibir en su casa a una agrupación de intelectuales compuesta por una veintena

${ }^{21}$ Joseph Hansen, "With Trotsky to the End", Fourth International, octubre, 1940.

${ }^{22}$ André Breton, La llave de los campos, op. cit., p. 56.

${ }^{23}$ Ibid., p. 55. 
ARMANDO PEREIRA

de personas venidas de Nueva York, y dar una breve charla, para responder posteriormente a sus preguntas, yo observé cómo a medida que él hablaba el clima de la habitación se le iba haciendo humanamente favorable; cómo aquel auditorio valoraba la vivacidad y seguridad de sus respuestas, le agradecía su cordialidad y disfrutaba con sus agudezas. Yo asistí muy divertido a los esfuerzos que aquellas gentes hicieron, antes de retirarse, por acercarse, uno tras otro, a darle las gracias, a estrecharle la mano... Esta seducción me parece que estriba no solamente en el placer de observar de cerca el funcionamiento de una inteligencia superior, sino también en el asombro de constatar que la preocupación fundamental sobre la que se centra esa inteligencia posee fuerza suficiente para someter a todas las demás. ${ }^{24}$

Mientras se estructuraba la relación de los dos amigos entre viajes y largas conversaciones, de los que nunca estuvo ausente el pintor Diego Rivera y que favorecían proyectos de trabajo intelectual conjunto, la prensa comunista inglesa y francesa no cesó en sus ataques, cargados de calumnias y falsías, ya no sólo contra el poeta surrealista, sino ahora también contra Trotsky, Rivera y el gobierno mexicano; concretamente se trataba, en ellas, de enfrentar al líder revolucionario en el exilio contra el país que lo había recibido. Detallo a continuación, siempre siguiendo de cerca el texto de Breton, algunas de esas mentiras arteras, que resultaban incluso contradictorias entre sí:

1. Se ha dicho, y el semanario Marianne se ha hecho eco de ello, que Trotsky había inspirado al presidente Cárdenas las medidas de expropiación que éste tomó a principios de año contra las compañías petrolíferas extranjeras (inglesas y americanas). ¡Y ello con el fin de poder enviar petróleo mexicano a Hitler, a Mussolini y a Franco!

2. Se ha sostenido - en contradicción formal con la alegación primera-que era Trotsky quien había fomentado contra el presidente Cárdenas la rebelión del general Cedillo.

3. Han llegado incluso a asegurar que los camaradas Trotsky y Rivera, en el curso de un viaje de México a Guadalajara [...], durante el cual yo no me he separado de ellos, habían mantenido largas entrevistas con un tal ${ }^{24}$ Ibid., pp. 55-6. 
doctor Atl, que allí pasa por ser un agente de la embajada alemana. ¡Era a mí, simplemente - exclama Breton ofendido-, a quien se pretendía hacer pasar por ese fascista!

4. Se sugiere que el camarada Trotsky sostiene demasiado buenas relaciones con el Gobierno mexicano y que se preocupa menos de sostener los intereses de la clase obrera mexicana que de adular al general Cárdenas, debido a la hospitalidad que de él recibe. ${ }^{25}$

\section{La respuesta de Trotsky fue contundente:}

Abandonemos a bufones e intrigantes a su propia suerte. No es de ellos de quienes nos ocupamos, sino de los obreros conscientes del mundo entero. Sin hacerse ilusiones ni espantarse de las calumnias, los obreros avanzados ofrecerán un apoyo total al pueblo mexicano en su lucha contra los imperialismos. La expropiación del petróleo no es ni socialismo ni comunismo, pero sí una medida profundamente progresista de autodefensa nacional. [...] Sin abandonar su propia imagen, toda organización obrera honesta del mundo entero, y sobre todo de Gran Bretaña, está obligada a atacar implacablemente a los bandidos imperialistas, a su diplomacia, a su prensa y a sus lacayos fascistas. La causa de México, como la causa de España, como la causa de China, es la causa de toda la clase obrera. ${ }^{26}$

Pero durante los cuatro meses que pasó Breton en México las críticas y calumnias contra él, Trotsky y Diego Rivera no cesaron, ya no sólo en la prensa europea, sino ahora también en la prensa mexicana. El foco de esas críticas lo constituyeron fundamentalmente el poeta francés y el pintor mexicano, y en particular el movimiento surrealista que Breton representaba. No voy a seguir aquí el curso de esas polémicas, que en realidad nunca fueron polémicas, pues Breton decidió no responder a ellas, sino francas diatribas por una parte (algunos periodistas e intelectuales mexicanos de clara orientación comunista), e intentos de explicación de lo que era la poesía y la pintura surrealista por otra (las entrevistas y conferencias que Breton ofreció en México).

${ }^{25}$ Ibid., p. 57.

${ }^{26}$ Ibid., pp. 57-8. 
ARMANDO PEREIRA

No voy a detenerme en ellas, además, porque en ningún momento se trata de artículos serios, responsables, que discutan ideas políticas o estéticas; se trata únicamente, como obedeciendo directrices superiores, de desacreditar, por la vía de la burla, la ridiculización y el sarcasmo, a un movimiento poético - el surrealismo-y a su fundador: André Breton. No me parece que esos lamentables insultos, nacidos más de intestinos furiosos que de una racionalidad reflexiva, merezcan comentario alguno. Por lo demás, ya Fabienne Bradu se ha encargado de ellos, de una manera exhaustiva y esclarecedora, en su libro André Breton en México, en el que reproduce completo cada uno de esos artículos. $^{27}$

Pero lo que sí quiero recalcar es que el ambiente enrarecido que desde su llegada rodeó al poeta francés en la ciudad de México terminó afectando la labor intelectual que iba desempeñar aquí. Del ciclo de conferencias que debía impartir en la Universidad Nacional Autónoma de México, sólo se llevó a cabo la primera: "Las transformaciones modernas del arte y el surrealismo", el 13 de mayo en San Ildefonso, ante un auditorio concurrido y entusiasta. El pretexto para interrumpir el ciclo fue la crisis por la que en ese momento atravesaba la Universidad, que la llevaría a la larga a cerrar sus puertas. No hace falta demasiada suspicacia para suponer que el sabotaje político a Breton alcanzó incluso a las esferas académicas, que en ningún momento aceptaron trasladar las conferencias a auditorios extrauniversitarios.

De cualquier forma, la relación entre los tres amigos -Trotsky, Breton y Rivera- no se vería afectada en lo más mínimo por toda esa serie de ataques y sabotajes. Esa relación continuaría y con frutos significativos, en particular uno de ellos: el manifiesto Por un arte revolucionario independiente, redactado fundamentalmente por Trotsky y Breton, aunque aparecería firmado sólo por Breton y Rivera.

Para iniciar la redacción del manifiesto, deciden encontrarse en Pátzcuaro, un lugar tranquilo y completamente a salvo de la algarabía ideológica de la ciudad de México, en donde debían llevarse a cabo varias reuniones hasta que los puntos esenciales del texto estuvieran decididos.

${ }^{27}$ Cfr. Fabienne Bradu, André Breton en México, op. cit. 
De esas reuniones, sin embargo, sólo pudo realizarse la primera, pues al día siguiente del primer encuentro, inexplicablemente, Breton amanece aquejado de afasia. En una carta escrita semanas después, desde el barco que lo devuelve a Francia, el poeta francés trata de explicarle a Trotsky las posibles razones de su repentina enfermedad:

Esta inhibición se debe ante todo, quisiera que lo entendiera muy claramente, a la admiración sin restricciones que usted me inspira. Sólo fue, en esos días, el reverso de la medalla. Así, a menudo me he preguntado lo que sucedería si, a pesar de la imposibilidad, me encontrara frente a frente con uno de esos hombres gracias a los cuales modulé mi pensamiento y mi sensibilidad: digamos, por ejemplo, Rimbaud o Lautréamont. Me sentía, entonces de pronto privado de mis medios, presa de una perversa necesidad de ocultarme. Es lo que llamo para mí, en recuerdo del Rey Lear, mi complejo de Cordelia; no se burle, es un fenómeno de mi naturaleza, orgánico y, creo, irremediable. Usted es precisamente uno de esos hombres y quizá - no estoy seguro a causa de Freud- el único vivo. $^{28}$

¿Cómo entender, en realidad, esta carta de disculpa? ¿Cómo entender que un hombre dueño de las palabras, de todas la palabras, cuyo oficio es y ha sido toda su vida el trasiego con las palabras, pierda de pronto la palabra, o confunda unas palabras con otras, o se declare incapaz de pronunciarlas, de hablar convenientemente? ¿Sólo por la admiración que el interlocutor le inspira? ¿La admiración puede llevar a uno de los más grandes escritores del momento a perder el habla, a enmudecer? Me cuesta un poco creer que la admiración, por grande y honda que sea, pueda llevar al Señor de las Palabras a quedarse sin palabras, a tartamudear, a decir unas cosas por otras, a perder su más valioso instrumento. Además, hablaban en francés. Era la lengua de Breton, en la que había nacido y escrito toda su obra; la segunda lengua

${ }^{28}$ Citado por Fabienne Bradu, op. cit., p. 201.

${ }^{29}$ La respuesta de Trotsky a la carta de Breton fue tan escueta como contundente: "Sus elogios me parecen tan exagerados que empiezo a sentirme un poco preocupado por el futuro de nuestras relaciones." Citado en Isaac Deutscher, Trotsky: el profeta desterrado (1929-1940), 1971, México, Ediciones Era, p. 389. 
de Trotsky, que sólo utilizaba para comunicarse. Definitivamente, un efecto de esa naturaleza, la derrota de la lengua madre de un poeta por la lengua vicaria de un político, no proviene tanto de la admiración sino del miedo. (Es verdad que en los resquicios de toda admiración habita siempre una buena dosis de miedo.) Precisamente el miedo que una figura de poder, incluso destronada, puede producir en un hombre que, aunque su obra diga todo lo contrario (el surrealismo es un juego de palabras que se ríe en las narices del Canon), respeta demasiado (y se somete) a ese poder.

Al llegar a México, Breton encontró en Trotsky lo que no había encontrado en Francia: la posibilidad de un acuerdo en los planos político y estético que para él resultaban esenciales. Aunque también hay que señalar que si bien los puntos de acuerdo fueron muchos, no fueron menos sus diferencias. No creo que los juegos verbales del surrealismo entusiasmaran demasiado al revolucionario ruso (como tampoco entusiasmaron a Freud) que buscaba, a través de la IV Internacional, la impostergable revolución mundial. A esto se ha referido también Isaac Duetscher en su biografía sobre el revolucionario ruso: "La actitud de Trotsky frente al surrealismo [...] era más bien amistosa, sin dejar de ser crítica: él aceptaba la concentración cuasi freudiana de los surrealistas en los sueños y en la experiencia subconsciente, pero veía con recelo una 'vena de misticismo' en la obra de Breton y sus compañeros". ${ }^{30}$

Breton, por su parte, venía ya de incontables rupturas políticas y estéticas, y creo que antes de asumir plenamente los puntos de desacuerdo (porque sin duda los hubo; tal vez por eso Trotsky se negó a firmar el manifiesto) con esa figura fuerte de poder que Trotsky representaba, antes de aceptar una ruptura más que para él resultaría definitiva, el poeta dueño de las palabras prefirió enmudecer, dejar de decir lo suyo para asumir las palabras, todas las palabras, del Otro, ese gran líder revolucionario cuya sombra pesaba aún con fuerza sobre el mundo.

No era la primera vez que Breton sufría un ataque de afasia. Le había ocurrido lo mismo años atrás, en 1921, cuando visitó a Freud en Viena.

${ }^{30}$ Isaac Deutscher, op. cit., p. 390. 
También allí palidece, trastabilla con su lengua (que no era la de Freud), enmudece, cede todas las palabras al psicoanalista vienés. Esto hace pensar que Breton, sin duda, tenía un serio problema con la autoridad, tanto en el plano de la acción como en el plano del pensamiento. Y que su única manera de responder ante esas grandes figuras investidas del poder que otorga la acción revolucionaria o la inauguración de un nuevo campo de saber, era enmudeciendo, anulándose a sí mismo, tropezando con la lengua, como un niño torpe, devuelto a sus primeros pasos, ante la mirada vigilante de papá.

A pesar de ese momentáneo e infantil ataque de afasia, Breton logra redactar una primera versión del manifiesto Por un arte revolucionario independiente a la que Trotsky hará algunas precisiones hasta alcanzar su versión definitiva, que aparecerá publicada, sólo con las firmas de André Breton y Diego Rivera, el 25 de julio de 1938. El manifiesto comienza advirtiendo el peligro que significan, para el arte y la ciencia, los dos sistemas totalitarios que imperan en ese momento en Europa: fascismo y estalinismo. Si el primero, "tras haber erradicado de Alemania a todos los artistas en los que se expresaba en algún grado el amor a la libertad, aunque sólo fuese formal, ha obligado a los que aún podían consentir en someter un pincel o una pluma a convertirse en lacayos del régimen y a alabarlo por orden en los límites externos del más mediocre convencionalismo", ${ }^{31}$ con el segundo ha ocurrido algo peor:

Bajo la influencia del régimen totalitario de la U.R.S.S. y por intermedio de los organismos llamados 'culturales' que ella controla en los demás países, se ha extendido por el mundo entero un profundo crepúsculo hostil a la emergencia de cualquier especie de valor espiritual. Crepúsculo de fango y de sangre en el que, disfrazados de intelectuales y artistas, se sumen hombres que han hecho del servilismo un móvil, de la negación de sus propios principios un juego perverso, del falso testimonio verbal una costumbre, y de la apología del crimen un placer. El arte oficial de la época estaliniana refleja, con una crueldad sin paralelo en la historia,

${ }^{31}$ André Breton y Diego Rivera, "Por un arte revolucionario independiente", en $L a$ llave de los campos, op. cit., p. 42. 
ARMANDO PEREIRA

sus irrisorios esfuerzos por aparentar lo que no es y enmascarar su verdadero papel mercenario. ${ }^{32}$

A este intento de los regímenes autoritarios a someter el arte a fines políticos e ideológicos específicos y a hacer del artista un corifeo de la voz del amo, el manifiesto responde de una manera contundente:

La libre elección de temas y la absoluta no-restricción en cuanto concierne al campo de su exploración, constituyen para el artista un bien cuyo derecho ha de reivindicar como inalienable. En materia de creación artística, importa esencialmente que la imaginación escape a todo constreñimiento y que se deje señalar el camino bajo ningún pretexto. A quienes nos apremien, sea para hoy o para mañana, a consentir que el arte sea sometido a una disciplina que consideramos radicalmente incompatible con sus medios, opongamos un repudio inapelable y nuestra deliberada voluntad de atenernos a la fórmula: total licencia en el arte. ${ }^{33}$

En ningún momento los autores del manifiesto postulan un "arte puro", desligado de las necesidades y anhelos más hondos y vitales del hombre, pero tampoco, y mucho menos, un arte constreñido a las necesidades sociales e históricas concretas, y sometido al "espíritu policiaco reaccionario, ya sea representado por José Stalin, o por su vasallo García Oliver. [...] El arte revolucionario independiente debe aunarse en la lucha contra las persecuciones reaccionarias y proclamar muy alto su derecho a la existencia". ${ }^{44}$ Y para cumplir con este objetivo, los autores del documento concluyen llamando a la creación de la Federación Internacional del Arte Revolucionario Independiente (F.I.A.R.I.), que consideran fundamental para velar por esa libertad irrestricta del artista, única condición esencial para que el arte pueda vincularse de una manera verdaderamente eficaz, creativa y enriquecedora con la sociedad en la que se inscribe.

A raíz de la publicación del manifiesto, se fundará la Fedération Internationale de l'Art Independant, con adhesiones importantes de

${ }^{32}$ Ibid., pp. 42-3.

${ }^{33}$ Ibid., p. 44.

${ }^{34}$ Ibid., p. 46. 
escritores y artistas tanto en Francia como en México, y las cálidas palabras de acogida que el propio Trotsky les dedica en una carta a Breton publicada en Partisan Review en el otoño de 1938:

Yo acojo de todo corazón la idea suya y de Rivera de fundar una Federación Internacional de Artistas verdaderamente revolucionarios y verdaderamente independientes $[\ldots]$ ¿y por qué no añadir de verdaderos artistas? [...] Nuestro planeta se está convirtiendo en un asqueroso y maloliente cuartel imperialista. Los héroes de la democracia [...] hacen todo lo posible por parecerse a los héroes del fascismo [...] y mientras más ignorante y obtuso es un dictador, más destinado se siente a dirigir el desarrollo de la ciencia, la filosofía y el arte. El instinto de rebaño y el servilismo de la intelectualidad constituyen un síntoma más, y no insignificante, de la decadencia de la sociedad contemporánea. ${ }^{35}$

La vida de la recién fundada Federación sería, sin embargo, efímera y sin mayor trascendencia en la vida cultural francesa y mexicana. Dos acontecimientos lo impidieron: el desencadenamiento de la Segunda guerra mundial en Europa y el asesinato de Trotsky en México, en agosto de 1940, a manos de Ramón Mercader, ciego y fiel ejecutor de las órdenes de Stalin.

La despedida entre Breton y Trotsky en la 'casa azul' de Coyoacán es definitivamente calurosa y, más allá de las posibles diferencias entre los dos, termina sellando con fuerza una segura amistad. Ese día Trotsky le entrega a Breton el manuscrito común del manifiesto y, en correspondencia, Breton le obsequia una fotografía con la siguiente dedicatoria:

A Leon Trotsky, en recuerdo de los días vividos en su luz, con mi admiración y lealtad absolutas. André Breton, México, 30 de julio de $1938 .^{36}$

\footnotetext{
${ }^{35}$ Citado en Isaac Deutscher, op. cit., p. 390.
}

${ }^{36}$ Citado por Fabienne Bradu, op. cit., p. 226. 
CITAM Derechos Reservados.

La reproducción total o parcial de este artículo se podrá hacer si el ITAM otorga la autorización previamente por escrito. 